\title{
Performance Indicators in the Wine Supply Chain Context: a Framework for Explanation and Action
}

Laurence Saglietto, François Fulconis, Gilles Paché and Raymundo Forradellas

\section{(2) OpenEdition \\ 12 Journals}

Electronic version

URL: https://journals.openedition.org/rei/6422

DOI: $10.4000 /$ rei.6422

ISSN: $1773-0198$

Publisher

De Boeck Supérieur

\section{Printed version}

Date of publication: 15 September 2016

Number of pages: 99-141

ISBN: 9782807390577

ISSN: 0154-3229

Electronic reference

Laurence Saglietto, François Fulconis, Gilles Paché and Raymundo Forradellas, "Performance Indicators in the Wine Supply Chain Context: a Framework for Explanation and Action", Revue d'économie industrielle [Online], 155 | 3e trimestre 2016, Online since 15 September 2018, connection on 02 June 2022. URL: http://journals.openedition.org/rei/6422 ; DOI: https://doi.org/10.4000/rei.6422 


\title{
PERFORMANCE INDICATORS IN THE WINE SUPPLY CHAIN CONTEXT: A FRAMEWORK FOR EXPLANATION AND ACTION
}

\author{
Laurence Saglietto, Université Côte d'Azur, CNRS, GREDEG, France \\ François Fulconis, CRET-LOG (Aix Marseille Université), \\ Université d'Avignon, France \\ Gilles Paché, CRET-LOG, Aix-Marseille Université, France \\ Raymundo Forradellas, CEAL, Universidad Nacional de Cuyo Mendoza, Argentina
}

Keywords: Modelling, Performance, Social Network Analysis, Traceability, Wine Supply Chain.

Mots-clés : Modélisation, performance, analyse des réseaux sociaux, traçabilité, chaîne logistique du vin.

\section{INTRODUCTION}

Measuring supply chain performance has been an important topic in the literature for over 20 years (Stewart, I995; Beamon, I999; Tan et al., I999; Brewer and Speh, 2000; Chan, 2003; Gunasekaran et al., 2004; Flynn et al., 20IO; Mackelprang et al., 20I4; Wu et al., 20I4; Gligor et al., 20I5). Debate has become quite heated over what is the most appropriate focus for analysis. Is it the performance of individual supply chain members? Should it be the performance interface among supply chain members? Or should it be based on the perceptions of the consumers at the end of the supply chain? No definitive answer has been achieved. Nevertheless, regardless of which performance should be measured, and how it should be measured, the fact remains that a poorly performing supply chain can destroy value for 
its members, especially in terms of market share (Stank et al., 2003). For example, an automotive manufacturer will suffer significant sales losses if the suppliers of materials and components are unable to meet its rigorous procurement schedules, resulting in downtime and disruption to delivery schedules.

Sectors such as the automotive industry, but also the personal computer, convenience goods and retailing industries have attracted attention with regard to the performance of their supply chains. However, in the case of the wine industry, despite Franken's (2014) focus on the use of formal coordination mechanisms in the California wine grape supply chain, quality considerations have been paramount to protect investment in special assets. The reasons for the lack of interest in the wine supply chain (WSC) are: (I) the traditional character of the industrial and logistical processes; and (2) a product aimed at a gourmet clientele which, primarily, is searching for thrills in terms of taste. However, the WSC has several features that are similar to a traditional supply chain, such as the ability to respond to volatile demand, to control costs in a hyper-competitive environment, and to satisfy increasingly segmented markets (Chandes and Estampe, 2003; Flint et al., 2016). Measuring the performance of the WSC, beyond measuring production yields or wine quality, requires a long-term vision related to increasing the visibility of the global supply chain in order to conform to the models of the manufacturing and large retailing industries. To ensure sustainability of the WSC requires total visibility of the flow of products and information designed to reduce costs and improve operational performance.

According to Heaney (2013), collaborative synchronisation among all members in the global supply chain is key to ensuring a high level of responsiveness, control of deadlines and cost control. Indeed, "visibility is a prerequisite to supply chain agility and responsiveness" (Heaney, 2013, p. 2). Based on a survey of 149 global supply chain companies, Heaney (2013) uses various performance indicators to identify two groups of stakeholders: leaders and followers. The 30 leaders he identifies follow global standards (GSI) relating to traceability in the supply chain. Large companies that adhere to GSI have higher requirements related to control and coordination of links with external partners on which they depend. GSI is a neutral nonprofit international organisation that develops standards and solutions to improve the efficiency and visibility of the supply chain in various 
industries ( 2 million business users in IIo countries). These include: Supply Chain Visibility (Heaney, 2013), WSC Traceability Guideline (GSI, 2005, 2008), and Performance Measurement (GSI, 20I4). All the GSI works highlight the importance of synchronisation among supply chain members. However, there are no suggestions about how to manage interactions and measure performance despite these issues being crucial to success.

In an attempt to fill this gap, we study how to assess the performance of the WSC as a network of different companies configured to procure, produce, and distribute materials and finished goods. The relational performance is based on mutual trust between WSC members and can be measured by concrete indicators. To the extent that it is little studied in the literature, it is interesting to focus on the interactions between WSC members in order to suggest a complementary performance approach. Our objective is twofold: (I) to understand WSC performance, and (2) to suggest potential improvements. This requires using a relevant method that has been applied in the management literature to map the WSC, in other words, an analysis of all the WSC members that shows how each of them is connected. The model is based on supply chain mapping to provide a visual representation of the network structure comprised of exchanges between WSC members. We describe the model's main characteristics in terms of boundaries, actors, linkages, relationships, and flows. In brief, the stated objective is to provide a performance measurement and metrics in connection with the standardisation of traceability through a social network analysis (SNA).

The structure of this paper is as follows. In Section I, we describe the chosen modelling framework, using five elements: actors, boundaries, links, relationships, and flows. In Section 2, we propose performance indicators for 2I dyadic relationships. Section 3 discusses what these indicators measure and examines joint control of traceability of flows and performance. We conclude by referring to the collective performance of business networks and the contribution of this approach to industrial organisation theory. This paper aims more generally to highlight the need for the implementation of global traceability standards to facilitate the monitoring of supply chains as inter-organisational systems ${ }^{\mathrm{I}}$.

I This work was supported by cooperation program ECOS-sud/MINCyT that provided the initial framework for the collaboration between University of Nice SophiaAntipolis-GREDEG CNRS, France and Universidad Nacional de Cuyo Mendoza, 


\section{SNA MODELLING}

Mapping the WSC is a complex exercise which raises the question of what is the structure of the WSC. There are several possible approaches to this issue: the supply chain approach using a descriptive method (Stevenson, 20I4), a generic approach (Handfield and Nichols, I999; Chen and Paulraj, 2004), a general systems approach (Caddy and Helou, 2007; Liu, 20II), and a complex approach (Cooper et al., 1997; Lambert et al., 1998). Supply chain modelling needs to be based on a holistic approach and, according to Seal et al. (I999, p. 304), "it is more proper to think in terms of a supply network rather than a chain of firms". To tackle this complexity, Cooper et al. (1997) and Lambert et al. (1998) propose a modelling of the supply chain network that includes three structures: (I) the type of supply chain partners (primary and secondary); (2) the structural dimensions of the supply chain network (horizontal and vertical); and (3) the characteristics of the supply chain links among partners.

We opted for an original model of the supply chain based on SNA (Lazzarini et al., 200I; Lee, 2005; Ellram et al., 2006; Carter et al., 2007; Mueller et al., 2007; Borgatti and Li, 2009; Galaskiewicz, 20II; Kim et al., 20II). SNA provides an original theoretical and management perspective. SNA prioritises social structures. For example, Bortoluzzi et al. (2015) measure the level of a firm's social interactions in terms of frequency and intimacy of contact with other firms and institutions located in a cluster, which allows a firm to collect relevant information about its business more efficiently. In brief, the behaviour of individual units can be explained by the social environment in which they operate. The size and shape of networks can vary, but all are inseparable from social life; all individuals have social relationships which can be modelled. Several researchers discuss the relevance of social network theory in the supply chain context (Lazzarini et al., 20or; Ellram et al., 2006; Carter et al., 2007; Mueller et al., 2007; Borgatti and Li, 2009; Kim et al., 20II; Galaskiewicz, 20II; Bellamy and Basole, 2013; Wang et al., 20I6). They underline the key components of a network, and propose indicators for node level (node degree, node closeness centrality, and node

Argentina (Project AıзHo2). The authors would like to thank two anonymous reviewers of the Revue d'économie industrielle for their insightful comments on the first version of this paper, as these comments led us to a significant improvement of the work. 
betweenness centrality) and network level (density, centrality, complexity). Our implementation of SNA to model the WSC involves five elements.

\subsection{Actors}

The network nodes are the WSC actors. Our aim is to reflect the diversity, rather than the number, of actors. Each actor is a community and our objective is to present a simplified representation (see Table I). SNA provides a comprehensive overview of a complex system of relationships and the position, role, and relationships of each actor (Granovetter, I985; Wasserman, I994; de Nooy et al., 2005; Knoke and Yang, 2008). For example, adherence to GSI standards facilitates connections among all the actors in the supply chain both upstream and downstream. The GSi numbering and bar code system applies throughout the WSC-from grape grower to retailerand provides traceability. For example, the grape grower is responsible for grape production. Each plot or block of vines is identified by a global location number (GLN), which is allocated by the grape grower. After transformation from grape juice to wine, the wine producer assigns an additional product identifier or global trade identification number (GTIN), a standard subject identification code (SSCC) or shipping container identification, and a code indicating the quantity of wine dispatched (AI):

- The GLN is a numeric code that identifies the legal entity (company subsidiary), function (e.g. accounting department) or physical element (e.g. a plot of land) in the company or organisation. A unique number is assigned to each site. Using a GLN is essential for electronic data interchange;

- The GTIN is a number that enables the unique and universal identification of commercial units. A business unit is any item-a product or service-which requires retrieval of predefined information to affix a price. The GTIN enables the item to be ordered or invoiced for trade at any point in the supply chain;

- The SSCC is a number that allows unique identification of shipping units (e.g. a removable tank or container). A shipping unit is any type of item created for transport and/or storage which needs to be managed along the supply chain. All supply chain members can use this number as a reference to electronically access information in the files; 
- The AI transcribes all the product attributes that refer to mandatory information to complement the strict identification of a business unit or shipping unit, such as lot number, production date, or consumer. The attributes are displayed as bar codes in the GSI-I28 symbol.

Tableau 1. Definition of players/actors of the WSC

\begin{tabular}{|c|c|}
\hline Actors & Definitions \\
\hline $\begin{array}{l}\text { Raw } \\
\text { material } \\
\text { supplier }\end{array}$ & $\begin{array}{l}\text { Raw material suppliers provide wine producers and fillers/packers with } \\
\text { all the supplies needed for wine-making or filling and packing. The main } \\
\text { activities are: receive new orders from wineries and/or fillers/packers, } \\
\text { prepare orders, send supplies to the wineries and fillers/packers, store } \\
\text { supplies, etc. }\end{array}$ \\
\hline $\begin{array}{l}\text { Grape } \\
\text { grower }\end{array}$ & $\begin{array}{l}\text { Grape growers are responsible for the production and harvest of } \\
\text { the grapes. The main activities of grape growers are: planting the } \\
\text { grapes, cultivating and pruning the vines, eliminating the inadequate } \\
\text { vineyards, fertilising the vineyards, controlling plagues, harvesting } \\
\text { grapes, etc. }\end{array}$ \\
\hline $\begin{array}{l}\text { Wine } \\
\text { producer }\end{array}$ & $\begin{array}{l}\text { Wine producers are responsible for receiving grapes, the elaboration, manu- } \\
\text { facture and/or blending of wine products. In general, the main activities to } \\
\text { elaborate wine are: receiving and weighing the grapes, crushing, stemming } \\
\text { and pressing juice, addition of sulfites and decanting, addition of yeast, } \\
\text { fermentation, refrigeration, clarification and stabilisation, temperature } \\
\text { control, preparation for bottling, maturation in bottle, etc. }\end{array}$ \\
\hline $\begin{array}{l}\text { Cooperative } \\
\text { winery }\end{array}$ & $\begin{array}{l}\text { A group of grape producers join their resources to own a winery } \\
\text { at a lower cost per unit by maximising the production volume. } \\
\text { Grape producers bring their grape at the winery cooperative which } \\
\text { commercialises their wines to numerous customers: trader, restaurateur, } \\
\text { retailer and mass market distribution industry. }\end{array}$ \\
\hline $\begin{array}{l}\text { Bulk wine } \\
\text { distributor }\end{array}$ & $\begin{array}{l}\text { Bulk wine distributors are responsible for reception, storage, dispatch, } \\
\text { processing, sampling and analysis of bulk wine. They receive bulk wine } \\
\text { from the wine producer. The wine is usually pumped into transport } \\
\text { containers such as road tankers or barrels. When the wine arrives at the } \\
\text { "tank farm", the bulk distributor checks the receiving documents and } \\
\text { takes samples for tasting and analysis. He approves or rejects the wine } \\
\text { (if rejected, the wine returns to the nominated source). }\end{array}$ \\
\hline $\begin{array}{l}\text { Transit } \\
\text { cellar }\end{array}$ & $\begin{array}{l}\text { Transit cellars are responsible for the reception, storage, dispatch, } \\
\text { processing, sampling and analysis of bulk wine. They can be part of } \\
\text { the filler/packer company (geographically separated or not) or can be } \\
\text { outsourced. The transit cellar receives bulk wine from bulk distributors } \\
\text { in different kinds of containers. During the transit cellar stage, the wine } \\
\text { is prepared for onward sale and filling. It is loaded for transit to the } \\
\text { customer and is accompanied by all the appropriate documents. }\end{array}$ \\
\hline
\end{tabular}




\begin{tabular}{|c|c|}
\hline $\begin{array}{l}\text { Filler/ } \\
\text { packer }\end{array}$ & $\begin{array}{l}\text { Fillers/packers are responsible forth reception, analysis, filling, packing } \\
\text { and dispatch of finished goods. The filler/packer receives containers } \\
\text { of bulk wine from the wine producer, and then the wine is filled into } \\
\text { different kinds of packages. Consumer units, such as bottles, bag-in-box, } \\
\text { tetra packs, etc., are produced from The wine batches supplied. }\end{array}$ \\
\hline $\begin{array}{l}\text { Freight } \\
\text { forwarder }\end{array}$ & $\begin{array}{l}\text { Freight forwarders organise the shipment planning, which is the process } \\
\text { of choosing shipment frequencies and deciding for each shipment } \\
\text { which orders should be assigned. It also includes the safe and efficient } \\
\text { movement of goods on behalf of an exporter, importer or another } \\
\text { company or person, sometimes including dealing with packing and } \\
\text { storage. Typical activities include: researching and planning the most } \\
\text { appropriate route for a shipment (taking into account the nature of the } \\
\text { goods, cost, transit time and security), arranging appropriate packing } \\
\text { (taking into account climate, terrain, weight, nature of goods and cost) } \\
\text { and delivering or warehousing of goods at their final destination. }\end{array}$ \\
\hline $\begin{array}{l}\text { Freight } \\
\text { operator }\end{array}$ & $\begin{array}{l}\text { Freight operators supply service for transporting goods from the winery } \\
\text { to the importer or to other actors (distributor, wholesaler, retailer, etc.), } \\
\text { by air, through airline services, by sea through shipping lines or by road } \\
\text { and rail through different operators. The courier could be an express/ } \\
\text { parcel carrier trucking company, an ocean liner, a railroad or an air } \\
\text { carrier/integrator. }\end{array}$ \\
\hline Importer & $\begin{array}{l}\text { Importers buy goods from the wine producer and are responsible for } \\
\text { the reception, storage, inventory management and dispatching of } \\
\text { finished goods, which receives from the freight forwarder through the } \\
\text { freight operator. The importer sales and delivers finished goods to the } \\
\text { wholesaler or distributor of the destination country depending on the } \\
\text { distribution channel used in the country. }\end{array}$ \\
\hline $\begin{array}{l}\text { Finished } \\
\text { goods } \\
\text { distributor }\end{array}$ & $\begin{array}{l}\text { Finished goods distributors are responsible for the reception, storage, } \\
\text { inventory management and dispatching of finished goods, as well as re- } \\
\text { packing and re-labelling as per specific customer requirements required. }\end{array}$ \\
\hline Wholesaler & $\begin{array}{l}\text { Wholesalers receive pallets and cartons from the finished goods } \\
\text { distributors and pick and dispatch goods to the retails stores. They put } \\
\text { new orders to the finished goods distributor, to the importer and may } \\
\text { also buy directly from the winery. }\end{array}$ \\
\hline Retailer & $\begin{array}{l}\text { Retailers receive finished goods from finished goods distributors or } \\
\text { wholesalers depending on the distribution channel. They sell consumer } \\
\text { units (bottles, cartons) to the end consumer. The different sales' } \\
\text { channels are: hyper/supermarket, liquor stores, drugstores, specialist } \\
\text { store, hotels, restaurants, catering, clubs, etc. }\end{array}$ \\
\hline $\begin{array}{l}\text { End } \\
\text { consumer }\end{array}$ & $\begin{array}{l}\text { End consumers are the final actors of the supply chain. They may } \\
\text { buy finished goods directly from some wineries, or they can make an } \\
\text { indirect order of new products when they go to the store or supermarket } \\
\text { and chose some kind of wine. }\end{array}$ \\
\hline
\end{tabular}

Source: Adapted from GSI (2005, 2008), Garcia (2009) and Garcia et al. (2012). 


\subsection{Boundaries}

The groups of actors in the SNA include supply and production operations upstream and physical distribution operations downstream. These groups are composed of actors with relatively dense interlinks in the supply chain based on processing or services. The WSC includes three groups with specific functions, rules, and strategies, linked within the whole network of production group members, national market distributors, and international distributors (see Figure 2):

- Production group includes: (I) the grape grower; (2) the wine producer; (3) the bulk wine distributor; (4) the transit wine cellar; and (5) the filler/packer (Pretorius and Høj, 2005; GSI, 2005, 2008; Garcia, 2009). Upstream, the group maintains relationships with the raw material suppliers, and downstream, the group manages cellar door sales. This grouping varies across countries with different combinations of grape grower-wine producer-filler/packer triads.

- Distribution in the national market involves: (I) the finished good distributor; (2) the wholesaler; and (3) the retailer (Min and Zhou, 2002; GSI, 2005, 2008; Garcia et al., 2012). Upstream, the group maintains relationships with the filler/packer and downstream, the group maintains relationships with the end consumer. This modelling of the distribution group, related to the national market, varies among countries and may include the distributor-end consumer, retailerend consumer, wholesaler-end consumer, or cellar door sales-end consumer dyads, or the distributor-retailer-end consumer, distributor-wholesaler-end consumer, or wholesaler-retailer-end consumer triads.

- Distribution in the international market includes: (I) the freight forwarder; (2) the freight operator; and (3) the importer (Min and Zhou, 2002; Garcia et al., 2012). Upstream, the group maintains relationships with the filler/packer and downstream, the group maintains relationships with the end consumer. In the case of the international market, the wine is distributed via importers. The freight forwarder can be a conventional freight forwarder or a logistics service provider.

The elements of the mapping methodology used to construct the network are: (I) identifying all the members in the WSC, based on the practical and 
theoretical literature (GSI, 2005; Garcia, 2009; Garcia et al., 20I2); (2) setting the unit of analysis to study social relationships, "contractual relationships"; (3) investigating for every pair of actors whether the relationship exists (denoted $\mathrm{I}$ if it exists and $\mathrm{o}$ if it does not, according to the international rule adopted for graph drawing), and translating the results into a diagonal matrix; and (4) providing a representation using mapping software (UCINET in our case). Figure I depicts the network supporting the WSC. The general model proposed is the result of an international consensus. It allows the study of any WSC as it was built from the work of the international standards organisation (GSI) and confirmed by the scientific literature (Garcia et al., 20I2). From a theoretical point of view, the model is then complete and as such can be considered as the point of reference from which we can illustrate any WSC. For example, Appendix I, taken from Saglietto et al. (2016), uses the model to compare WSCs in Argentina and France.

Figure 1. The full network

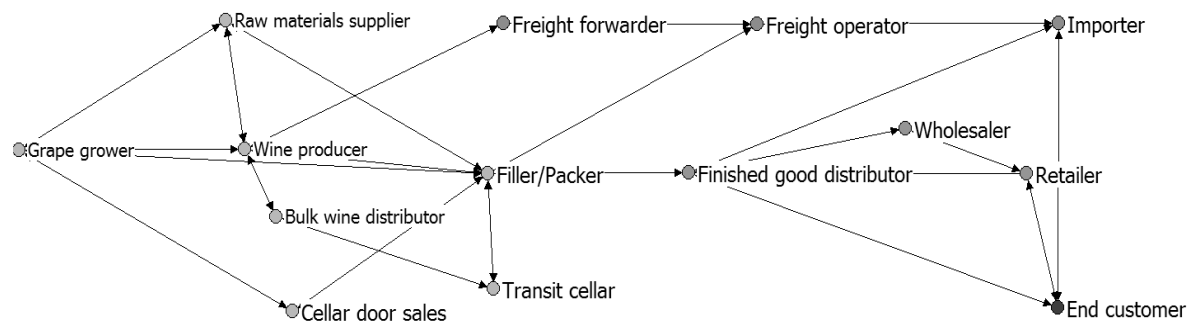

\subsection{Links}

The network links determine how the different actors (nodes) are connected and interact. These interactions are formal if the relationships associated with each link are formalised by contracts, and are informal if the links are established between actors based on coordination rules promoting trust and mutual support. The links are qualified by their content, intensity, frequency, and duration of trade. Thus, links in the WSC often become long term relationships. For example, Somogyi et al. (20I0) study the long term relationships between wineries and grape growers in Australia using a qualitative approach to identify the factors that enhance links. These are identified as communication, goal compatibility, and use of power. Somogyi et al. (2010) argue that a long term orientation 
can create barriers to competition, reduce price competition, and generate more revenue per consumer. Also, for the Australia wine industry, Islam and Quaddus (2005, p. 5) show that "uncertainties in various stages of the WSC are major reasons of undesirable behaviour of WSC dynamics", thus highlighting the difficulties involved in studying WSC performance.

In this paper, we investigate the formal links that allow increased coordination of operations and, thereby, contribute to the profitability of the actors involved in the process of production, marketing and physical distribution within the network. As underlined by Carmignani (2009, p. 40I), "for an entire supply chain to function effectively, it has to identify and manage numerous linked activities. An activity using resources and managed in order to enable the transformation of inputs into outputs, can be considered as a process". The nature and quality of the links between WSC members are described as relational cohesion, or the collective capacity to assemble the required resources. This relational cohesion can be assessed through trade commitments that unite supply chain members. Partnership agreements are representative of a certain degree of integration. A high level of integration within the supply chain contributes to better performance (Flynn et al., 20Io). The links in the network represent relationships and flows between nodes. The relationships are usually structural, based on contracts forged between the actors; flows refer to functional aspects related to physical exchanges (e.g. transportation, inventory management, and warehousing).

\subsection{Relationships}

Relationships define the framework in which the WSC actors interact. Fares (2009) emphasises the importance, in particular, of greater vertical integration in the WSC, and importance of brokerage activities in monitoring wine quality. Sidlovits and Kator (2007) analyse the forms of vertical coordination between wine grape producers and wine producers/ merchants by examining the characteristics of the contractual relationships in the Hungarian wine sector. Sidlovits and Kator (2007, p. I) show that "the uncertainty is extremely high in the sector especially in the field of price fluctuation, quality of raw materials, commercialisation and respect of obligations assumed in the contracts". They underline the observation that vine growers are not well organised at the level of negotiation with wine producers and merchants. Steiner (2012) analyses the same type of relationships and 
shows that "a grape grower contributes to final wine quality in terms of production efforts, and that the winery contributes in terms of processing and marketing efforts" (Steiner, 2012, p. 2). Pomarici et al. (2012, p. 24) point out that "the segment of WSC in charge of wine transfer to wineries and bottlers to actors delivering wine to consumers, may assume very different forms of organization".

It is usual to distinguish three types of relationships in the WSC: (I) membership relationships, for example, in a cooperative company; (2) contractual relationships related to the sale and purchase of materials and/or products; and (3) collaborative relationships to achieve a common goal. In our study, we use one unit of analysis to assess the WSC. We chose the various types of contractual relationships, including purchasing relationships (wine grape grower or producer and raw materials supplier, grape grower and producer who sells the wine grapes), contractual outsourcing relationships (freight forwarder), selling relationships, and norms (adoption of the same quality standards). The intensity of the relationship between WSC members is expressed through the connectivity among the three groups in the WSC as a network. This results in strong physical interconnections and/or informational links among WSC members.

\subsection{Flows}

A large number of studies on supply chain performance have been conducted since the early 2ooos. They focus on financial flows (Lambert and Burduroglu, 2000; Islam and Quaddus, 2005), physical flows (Mac Cawley, 20I4), information flows (Forbes et al., 20IO; Muchiri et al., 20I0), and more generally, logistical processes as business processes. This is because the logistical process is based on the management of flows from the supplier of supplier to the end consumer, requiring synchronisation between demand and supply and enabling maximum return on investment. In the supply chain context, command and control are essential for increasing the competitiveness of supply chain members (Frazelle, 2015). It is not possible to provide a supply chain modelling structure without explicit reference to flows.

In the WSC, through links previously built between the members, it is possible to identify different types of flows. Of particular importance are the physical flows (raw materials, semi-finished products, and finished 
products) and the information flows that enable monitoring of physical flows (Lam et al., 2013; Franken, 20I4; Song et al., 2016). Craighead et al. (2007) identify these three types of flows more precisely: (I) "forward" flow corresponds to the movement of materials and products from a WSC member located upstream to a WSC located downstream; (2) "backward" flow refers to the flow of materials from a WSC member located downstream to a WSC member located upstream (e.g. in the context of a reverse logistics); and (3) "within-tier" flow refers to the transfer of materials between two WSC members located at the same level in the supply chain.

\section{PERFORMANCE INDICATORS}

For several years, the traceability of food products, including wine, has been based on standardised approaches (Cimino and Marcelloni, 20I2), emphasising the actors and the raw materials, from suppliers to end consumers, including producers, logistics service providers, and others in the supply chain. In all countries, food traceability is subject to strict legal regulation (Folinas et al., 2006; Thakur and Hurburgh, 2009; Charlebois et al., 20I4). However, this standardisation could be improved and more strongly coupled to performance. The objective of this paper is to develop a link between standardisation of traceability and performance within the WSC by proposing a methodology that connects the two dimensions, using indicators on which all WSC members can rely. This approach is essential to improve two aspects of WSC dynamics: (I) the identification of potential operational problems in WSC monitoring; and (2) the definition of a set of guidelines to facilitate logistical decision-making (Garcia et al., 20I4). The link between standardisation of traceability and performance within the WSC is an additional motivation for the eventual implementation of global traceability standards. In the following sections, we first present GSi standards, followed by the identification of performance indicators.

\subsection{Reference to GS1 standards}

According to Engelseth (2009), standardisation of information on traceability requires several types of interoperability: (I) technical interoperability (formalisation of technical contract specifications, interfaces, interconnection services, data integration services, database formats, and information 
exchange protocols); (2) semantic interoperability (meaning information and techniques for developing information sharing); (3) organisational interoperability (cooperation among the actors to pursue mutually constructed objectives and logistical processes based on the exchange of information); and (4) legal interoperability (sharing of information beyond juridical boundaries). Traceability also requires global standards such as the WSC Traceability Application Guideline (GSI, 2005, 2008), which includes the required procedures and indicators. For example, Vukatana et al. (20I6) have recently used a data model along the lines of the GSI specifications for the WSC in the Albanian context.

Building on performance measurement standards (GSI, 20I4), and WSC traceability (GSI, 2005, 2008), we propose to create specific performance indicators. The aim is effectively to meet the mutual needs of WSC members to improve their ability to collaborate and exploit their collective technological capabilities, while remaining sufficiently agile to respond to changing demands, all within a secure environment. Implementation of this iterative process depends on two conditions: (I) a cooperation agreement among the WSC members to validate standardised indicators and calculation methods and to develop a nomenclature (code, definition, formula and frequency), and (2) a common trading scheme with operating information that allows WSC members to decide which tasks they will perform.

In practice, several models coexist and share the concept of a common database and exchange of information: (I) The interchange posting model allows companies to "exchange data through business-to-business transaction sets, using EDI, XML or flat file formats. The company-to-company model offers the advantage of standards based messages, and uses each company's own enterprise applications to analyse and act on the data" (GSI, 20I4, p. 57); (2) the hosted model "combines the benefits of ease of access of the extranet model with the data aggregation and single point of access of the company-to-company model" (GSI, 20I4, p. 57); and (3) an alternative model allows companies "to leave the measure data at its source rather than forwarding it to a partner or a shared service. Users access the data in place when they review their scorecard or other performance management application. Technology is responsible for requesting the values from their distributed sources, and assembling any views that combine them. The advantage of the distributed approach is that the data can remain wherever it was originally produced" (GSI, 20I4, p. 58). 


\subsection{Identifying the indicators}

To view the sequence of relationships among WSC members and to identify the performance indicators, we apply the WSC modelling presented above. We evaluate each dyad by identifying the contractual relationship between the actors according to the WSC Traceability Application Guideline (GSI, 2005, 2008). When the content is not in the guideline, it is precisely defined by the authors. The spatial and temporal representation of the proposed indicators is a digital balanced scorecard. Two points should be noted: (I) construction of the list of performance indicators facilitates classification in alphabetical order of all the indicators used and each indicator is then identified by a number of elements (shown in Table 2 and illustrated by an example); and (2) representation of all the performance indicators is organised according to the modelling of the WSC, based on location, dyadic relationship, nature of the contractual relationship, and adherence to the GSI standards. The relation between WSC membership and the traceability standard is an essential aspect of the analysis. It acts to connect two actors, from upstream to downstream in the WSC, within a mutually agreed social relationship. For example, the wine producer transmits information to the bulk wine distributor on the content and delivery of the order. Thus, the former provides to the latter the GTIN, lot number and identification of bulk wine containers (SSCC, GTIN, batch and amount received).

Tableau 2. Identifiers of performance indicators

\begin{tabular}{|l|l|}
\hline Performance indicator identifiers & \multicolumn{1}{|c|}{ Examples } \\
\hline Code & ANALYSIS I \\
\hline Localisation $^{*}$ & Production \\
\hline Objective & $\begin{array}{l}\text { Tasting analysis of all received wines, realised } \\
\text { by the person in charge of the cooperative }\end{array}$ \\
\hline Measure & $\begin{array}{l}\text { According to rules promulgated by the OIV } \\
\text { (transparency, limpidity, brightness) }\end{array}$ \\
\hline Results & $\begin{array}{l}\text { According to rules promulgated by the OIV } \\
\text { (transparency, limpidity, brightness) }\end{array}$ \\
\hline Maintenance & First test on xxxx 20I5; second test on xxxx 20I6 \\
\hline
\end{tabular}

* Localisation in relation with three identified markets.

At this specific stage, traceability is top down. The wine producer does not receive information on how the product is used by the bulk wine distributor. This information asymmetry is problematic in that it does not allow 
the wine producer to know whether its marketing action is relayed by the bulk wine distributor (for example, in terms of price strategy, consumer service, and staging of products). The feedback between the bulk wine distributor and the wine producer needs to be improved and made efficient. The proposed performance indicators are based on this feedback. The collaborative relationship between WSC members is the foundation for building the performance indicators in terms of the different received flows and the nature of the ongoing relationships. The construction is relevant in light of the theoretical works previously presented in this paper. Table 3 summarises the identification elements to be considered in all the dyadic relationships in the WSC.

Tableau 3. Performance indicators

\begin{tabular}{|l|l|}
\hline \multicolumn{1}{|c|}{ Key identification } & \multicolumn{1}{c|}{ Explanations } \\
\hline Localisation & $\begin{array}{l}\text { Three possible groups which compose the complete } \\
\text { network of the WSC): } \\
\text { - production, } \\
\text { - distribution on national market, } \\
\text { - distribution on international market. }\end{array}$ \\
\hline $\begin{array}{l}\text { Dyadic link } \\
\text { relationship }\end{array}$ & Link between two WSC members: actor I/actor 2. \\
\hline $\begin{array}{l}\text { Membership in the GS1 } \\
\text { standards }\end{array}$ & $\begin{array}{l}\text { Type of contract (sale, purchase, order delivery). } \\
\text { Collaboration relationship } \\
\text { standards. }\end{array}$ \\
\hline $\begin{array}{l}\text { Actor } 2 \text { returns information on the work realised by } \\
\text { relationships } \\
\text { terms of follow-up of the } \\
\text { various received flows }\end{array}$ & $\begin{array}{l}\text { actor } \text { I. Performance indicators break down into two } \\
\text { types: flows and follow up relationships. }\end{array}$ \\
\hline $\begin{array}{l}\text { Performance indicators in } \\
\text { the wine tasting results. }\end{array}$ & $\begin{array}{l}\text { Elements which have an impact on the nature of the } \\
\text { relationship so that it can be gradually defined, from } \\
\text { very good to very bad, in terms of order execution } \\
\text { (means of communication, information system), contract } \\
\text { negotiation and renegotiation, discharges, disputes, etc. }\end{array}$ \\
\hline
\end{tabular}

The performance indicators are specific to each dyadic relationship and are expressed in terms of monitoring the various flows received and monitoring the relationships maintained. In terms of monitoring the various flows, we propose indicators for service quality, effectiveness, possible improvements, various defects, tasting tests, and other factors. In 
terms of monitoring relationships, we propose indicators for factors that affect the nature of the relationship such that it can be defined on a continuum from very good to very bad, based on aspects such as dispatching and tracking of pallets, communication, information systems, negotiation and renegotiation of contracts, monitoring of discharges and real-time litigation. For example, Table 4 uses the relationship between the wine producer and the bulk wine distributor, as presented in Table 2, in order to demonstrate how performance indicators are created. The process was repeated for all of the relationships within the WSC.

Tableau 4. Example of performance indicators creation

\begin{tabular}{|c|c|c|}
\hline Key identification & Explanation & Source of information \\
\hline Localisation & Production. & $\begin{array}{l}\text { The full network } \\
\text { (Figure 2) }\end{array}$ \\
\hline Dyadic link & $\begin{array}{l}\text { Link between wine producer and bulk } \\
\text { wine distributor. }\end{array}$ & $\begin{array}{l}\text { The full network } \\
\text { (Figure 2) }\end{array}$ \\
\hline $\begin{array}{l}\text { Nature of the contrac- } \\
\text { tual relationship }\end{array}$ & Order delivery. & $\begin{array}{l}\text { GSI Standard } \\
(2005,2008)\end{array}$ \\
\hline $\begin{array}{l}\text { Membership in the } \\
\text { GS1 standards }\end{array}$ & $\begin{array}{l}\text { For each delivery, the wine producer } \\
\text { provides the bulk wine distributor } \\
\text { the GTIN and the batch number. The } \\
\text { identification of bulk wine containers } \\
\text { is recorded upon arrival. The bulk } \\
\text { wine distributor connects the relevant } \\
\text { characteristics to the wine to market. }\end{array}$ & $\begin{array}{l}\text { GSI Standard } \\
(2005,2008) \\
\text { Wine producer/bulk } \\
\text { wine distributor step }\end{array}$ \\
\hline $\begin{array}{l}\text { Collaboration } \\
\text { relationship }\end{array}$ & $\begin{array}{l}\text { The bulk wine distributor returns } \\
\text { information to the wine producer. }\end{array}$ & Our model. \\
\hline $\begin{array}{l}\text { Performance } \\
\text { indicators in terms } \\
\text { of follow-up of the } \\
\text { various received flows }\end{array}$ & $\begin{array}{l}\text { Sample tasting analyses results } \\
\text { depending on the type of product in } \\
\text { the container (mixed products, unique } \\
\text { product). } \\
\text { Quality and quantity of the shipping } \\
\text { container. } \\
\text { Type of preservation and storage. } \\
\text { Dispatching of products sold according } \\
\text { to type, quantity and recipient. }\end{array}$ & $\begin{array}{l}\text { GSI Standard } \\
(2005,2008) \\
\text { Bulk wine distributor/ } \\
\text { transit cellar step } \\
\text { GSI Standard (20I4) }\end{array}$ \\
\hline $\begin{array}{l}\text { Performance } \\
\text { indicators in terms } \\
\text { of follow-up of the } \\
\text { relationships }\end{array}$ & $\begin{array}{l}\text { Approval or refusal of the wine (in } \\
\text { case of refusal, the wine returns to the } \\
\text { designated source). } \\
\text { Quality of exchanges regarding refu- } \\
\text { sals and disputes on a real-time basis. } \\
\text { Order purchasing profile (communica- } \\
\text { tion means, information systems). }\end{array}$ & $\begin{array}{l}\text { GSI Standard } \\
(2005,2008) \\
\text { GSi Standard (2014) }\end{array}$ \\
\hline
\end{tabular}


The set of indicators refers to the 2I possible links, as indicated in Appendix 2, between raw material suppliers and grape growers; raw material suppliers and wine producers; raw material suppliers and fillers/packers; grape growers and wine producers; grape growers and fillers/packers; grape growers and cellar door sales; wine producers and bulk wine distributors; wine producers and fillers/packers; wine producers and freight forwarders; freight forwarders and freight operators; freight operators and importers; bulk wine distributors and transit cellars; transit cellars and fillers/packers; fillers/packers and finished good distributors; fillers/ packers and freight operators; finished good distributors and wholesalers; finished good distributors and retailers; finished good distributors and importers; finished good distributors and customers; retailers and end consumers; and importers and customers.

\section{DISCUSSION}

Explaining the supply chain using SNA is interesting. Supply chains are not linear structures; rather they are networks, sometimes described as supply networks or net chains (Lazzarini et al., 200I; Mueller et al., 2007; Kim et al., 20II). According to Carter et al. (2007, p. I37), SNA "can be applied both within and between organisations in a supply chain". SNA is used to investigate the structure of a network and to map the relationships among a group of actors. These relationships represent linking, communication, services and products. SNA describes and analyses the interrelationships among units or nodes within a network and can be used to map the complexity of the supply chain. Social network theory takes into account the social interactions that can influence the choices of supply chain actors and the supply chain itself, since no actor is isolated, but is part of a set of relationships which influence its choices. Thus, we agree with Borgatti and $\mathrm{Li}(2009, \mathrm{p} .8)$ who argue that "the ego network concept is probably the closest to a supply chain theorist's intuitive understanding of a supply network, but it is not a perfect match". We present the contributions of this paper, and then discuss some limitations. 


\subsection{Contribution}

If the network analysis has been applied for understanding supply chains previously, this is not the case for WSC. This article takes the position that application of SNA to wine markets is warranted, and it makes strides in identifying how that may be done. The paper clarifies a number of key concepts that will be useful to pursue empirical investigations in a second phase. The value of this approach seems undeniable as it leads to academic work, particularly in the field of supply chain management (Saglietto et al., 20I6.). It appears that the most common models, including the holonic approach (Dominici, 2008; Dominici et al., 2010), are not able to take into account the complexity on both the node level (node degree, node closeness centrality, and node betweenness centrality) and the network level (density, centrality, and complexity), as suggested in this paper. This article constitutes a step forward for a better understanding of the inter-organisational dynamics of WSC by viewing these supply chains in a new light.

The search for management and joint control of traceability and performance is a challenge in the inter-organisational context. It is aimed at assessing the viability and competitiveness of a network of actors. According to Dekker (2003, p. I), "inter-firm relationships introduce new challenges for management accounting. One such challenge is the provision of information for the coordination and optimisation of activities across firms in a value chain". The proposed indicators focus on the complete WSC network. From this point of view, we share the perspective adopted by Maturana and Valenzuela (2016) that in order to study the wine industry it is necessary to develop an inter-organisational performance measuring system. These indicators can be formalised and periodical procedures can be implemented through information systems. Use of these tools allows a link between the strategic and operational levels in addition to internal tools to calculate logistical costs and highlight the contribution of each actor to the creation of value (activity-based costing $[A B C]$ ).

The inclusion of indicators in a shared information system contributes to reduction in communication costs. Non-financial performance measures can be used to structure dialogue and exchange of information among WSC members. They provide collective support for each member's implicit and explicit objectives. WSC members interact and develop a collective 
strategy within a network governance context. The proposed indicators should strengthen the WSC by identifying deviance from agreed objectives. As already stated, the WSC is a network, i.e. a set of producers, processors, and traders that "gradually add value to products and services as they pass from one link in the chain to the next until reaching the final consumer (domestic or global)" (UNIDO, 20II, p. x). In this network, the various business activities are represented by different companies and their degree of coordination. Joint management and control of traceability and performance reveal conflicts of interest and levels of cooperation among WSC members and their underlying coordination mechanisms.

The proposed modelling could thus be useful for a better understanding of cooperative practices among WSC members, but more broadly, collaboration between the wine sector and other sectors. Research conducted by Mitchell and Schreiber (2007) on the cooperation within clusters in New Zealand indicate that the desire to establish a region-specific policy based on regional governance leads to connections between the tourism and wine industries. The goal is to create a strong regional identity or brand to generate a large flow of tourists. It is possible to cite here the case of the "Love Marlborough" brand, which combines tourism, wine, seafood and other food products. It appears that one of the most significant barriers for the implementation of effective regional clusters is the lack of recognition of wineries as part of the tourism industry. An SNA would be an interesting tool to identify conflicts of interest, but also the benefits that could be gained from a more robust cooperation for the benefit of each of the actors.

\subsection{Limitations and future research}

A social networking approach to understanding the dynamics of the WSC extends our knowledge in three dimensions: (I) the actors involved, (2) the relationships and links forged between them, and (3) the flows that structure the network in which they participate. A purely technical approach would restrict understanding of an "arcs and spots" type analysis. We have shown that SNA includes perspectives that have been mostly overlooked. It is possible to criticize the choice because it does not consider the formal (written) contractual relationships as nodes within the network. At least, for instance in the U.S. wine industry, we note the use of 
oral agreements, as indicated by Goodhue et al. (2003), but also the use of a series of informal mechanisms: sharing viticultural expertise, assisting with varietal selection and site selection, exchanging information via the Internet or e-mail, and discussing wine industry trends (Woods et al., 20II). Incontrovertibly, these oral agreements and informal mechanisms facilitate vertical coordination in the WSC and, more broadly, in the governance of economic transactions between organisations (Ferrary, 20Io).

As we have indicated, coordination rules that promote trust and mutual support can, indeed, play an important role in building links between WSC members. However, we preferred to devote ourselves to the analysis of the management of logistical processes based on tangible resources, similar to the work of Carmignani (2009). However, the use of intangible resources is an interesting approach in analysing the coordination of supply chains, as presented more recently in the literature (Duong and Paché, 20I5). Attention to informal relationships is also an important concept, opening the way towards a more holistic approach to analysis of WSC coordination. Like any research with an analytical and praxeological aim, our investigation has other limitations, which suggest research avenues. There are three additional main limitations:

- The limits of modelling. The model on which our argument rests is a simplification of the reality at a particular time and, therefore, can never perfectly reflect specific contexts, in particular in countries marked by different national cultures. However, the theoretical foundations of the model and the method of implementation can be extended to other supply chains. Our approach can, therefore, be compared to "an objectifying approach" in Bourguignon's (20I2) terms.

- The limits of stakeholder engagement. In a governance network, companies have complementary skills and common interests; they build a collective action which is based on the articulation of individual projects of interrelated businesses (Bréchet and Schieb-Bienfait, 2006). The benefits of including a traceability standard are difficult to demonstrate, but allow the identification of performance indicators. This WSC membership, however, generates costs of organisation and coordination. These costs are amplified if a company belongs to several supply chains with different standards, since product specifications are not always standardised. 
- The limits of performance indicators. To achieve our goal, we analysed a set of dyadic relationships to allow global optimisation. A shared vision among all WSC members can actually emerge in the presence of a computerisation of indicators open to all WSC members. Further research is needed along the lines of "open-book accounting", as a means of improving the efficiency of supply chain monitoring (Kajüter and Kulmala, 2005).

These limitations suggest directions for future research. First, the process of implementing indicators to improve the management of the WSC must be studied. Building on a systemic approach to the link between traceability and performance indicators, use of more generic monitoring tools might be possible. Performance indicators could then be implemented to enable monitoring and control along the lines of a balanced scorecard. Second, the appropriation of performance indicators through computerisation is required to make them more easily accessible and more precise. Ownership is essential to the success of the project as a cognitive process that allows each WSC member to access both individual and collective sources of knowledge in the implementation of best practices.

\section{CONCLUSION}

To evaluate and improve supply chain performance requires that it is defined, which can be difficult since each actor in the same supply chain may have a different vision. Defining supply chain performance criteria is essential to identify the most appropriate strategy to strengthen and increase competitiveness. Performance assessment indicators are needed to evaluate the whole supply chain and highlight the performance of different supply chain members (materials suppliers to end consumer) and their interrelationships, if the wine industry is to survive global competition in a borderless economy (Charters and Gallo, 20r4; Itçaina et al., 20I6). The proposed mapping approach and modelling links among the actors contribute to research on how the performance of the WSC can be assessed. Our choice of a little used method in this area, combined with mapping, allowed a focus on dyads of WSC members and identification of appropriate performance indicators. This approach complements the more traditional supply chain management tools which focus on creating value for the whole chain. 
The approach used in this paper is in line with models measuring supply chain performance. Given the complexity of the systems studied, if this approach does not favour a specific perspective (financial, informational, operational, strategic, suppliers, consumers, shareholders, societal, and environmental), it is precisely because it seeks to understand further the performance of the WSC by systemic analysis and modelling. Estampe (20I4) emphasises that performance evaluation cannot exist without models that identify value creation in the global supply chain. Traditional approaches to the potential for value creation among the members in a supply chain should be enriched by more inclusive approaches that use measures of performance in the relationships with key suppliers based on tangible and intangible resources (Philippart and Vieira, 20I4).

Evaluating supply chain performance is part of a more general assessment of inter-organisational network performance. From this point of view, work on inter-organisational networks, including supply chains, calls for research on collective performance to better understand the nature of the interactions between supply chain members. This could also satisfy the expectations expressed in terms of industrial organisation theory to better understand the structural changes faced by the manufacturing industry for decades. Changes in the organisation of production based on outsourcing strategies and the growth of supplier networks lead to the development of analyses in terms of global value chains (Bianchi and Labory, 2013). If their relevance is unquestionable, it seems important to look more carefully at the way they work and what is the level of performance achieved. For this, tools need to be developed, including more precise industrial policy recommendations.

\section{REFERENCES}

BEAMON, B. (1999), "Measuring supply chain performance", International Journal of Operations \& Production Management, Vol. 19, No. 3, pp. 275-292.

BELLAMY, M., BASOLE, R. (2013), "Network analysis of supply chain systems: a systematic review and future research", Systems Engineering, Vol. 16, No. 2, pp. 235-249.

BIANCHI, P., LABORY, S. (2013), "Structural transformations in industry and filières", Revue d'Économie Industrielle, No. I44, pp. I77-I99.

BORGATTI, S., LI, X. (2009), "On social network analysis in a supply chain context", Journal of Supply Chain Management, Vol. 45, No. 2, pp. 5-22. 
BORTOLUZZI, G., DE LUCA, P., VENIER, F., BALBONI, B. (20I5), "Innovation scope and the performance of the firm: empirical evidence from an Italian wine cluster", in Christiansen, B. (Ed.), Handbook of research on global business opportunities, IGI Global, Hershey (PA), pp. 55I-568.

BOURGUIGNON, A. (2012), “Enseigner les instruments de gestion : un piège éthique ?", Actes du $21^{e}$ Congrès National des IAE, Poitiers, pp. I-28 (CD-rom).

BRÉCHET, J.-P., SCHIEB-BIENFAIT, N. (2006), “Projets et pouvoirs dans les régulations concurrentielles: la question de la morphogenèse d'une filière d'agriculture biologique", Revue d'économie industrielle, No. I13, pp. 9-29.

BREWER, P., SPEH, T. (2000), "Using the balanced scorecard to measure supply chain performance", Journal of Business Logistics, Vol. 2I, No. I, pp. 75-93.

CADDY, I., HELOU, M. (2007), "Supply chains and their management: application of general systems theory", Journal of Retailing \& Consumer Services, Vol. I4, No. 5, pp. 319-327.

CARMIGNANI, G. (2009), "Supply chain and quality management: the definition of a standard to implement a process management system in a supply chain", Business Process Management Journal, Vol. I5, No. 3, pp. 395-407.

CARTER, C., ELLRAM, L., TATE, W. (2007), "The use of social network analysis in logistics research", Journal of Business Logistics, Vol. 28, No. I, pp. I37-I68.

CHAN, F. (2003), "Performance measurement in a supply chain", International Journal of Advanced Manufacturing Technology, Vol. 2I, No. 7, pp. 534-548.

CHANDES, J., ESTAMPE, D. (2003), "Logistics performance of actors in the wine supply chain", Supply Chain Forum: An International Journal, Vol. 4, No. I, pp. I2-27.

CHARLEBOIS, S., STERLING, B., HARATIFAR, S., NAING, S. (20I4), "Comparison of global food traceability regulations and requirements", Comprehensive Reviews in Food Science \& Food Safety, Vol. I3, No. 5, pp. IIO4-II23.

CHARTERS, S., GALLO, J., Eds. (20I4), Wine business management, Pearson, Paris.

CHEN, I., PAULRAJ, A. (2004), "Towards a theory of supply chain management: the constructs and measurements", Journal of Operations Management, Vol. 22, No. 2, pp. II9-I5O.

CIMINO, M., MARCELLONI, F. (20I2), "Enabling traceability in the wine supply chain", in Anastasi, G., Bellini, E., Di Nitto, E., Ghezzi, C., Tanca, L. Zimeo, E. (Eds.), Methodologies and technologies for networked enterprises, Springer, Heidelberg, pp. 397-4I2.

COOPER, M., LAMBERT, D., PAGH, J. (1997), "Supply chain management: more than a new name for logistics", International Journal of Logistics Management, Vol. 8, No. I, Pp. I-I4.

CRAigheAd, C., BlaCKHURST, J., RUNGTUSANATHAM, M., HANDFIELD, R. (2007), "The severity of supply chain disruptions: design characteristics and mitigation capabilities", Decision Sciences, Vol. 38, No. I, pp. I3I-I56.

DE NOOY, W., MRVAR, A., BATAGELJ, V., Eds. (2005), Exploratory social network analysis with Pajek, Cambridge University Press, Cambridge.

DEKKER, H. (2003), "Value chain analysis in inter-firm relationships: a field study", Management Accounting Research, Vol. I4, No. I, pp. I-23.

DOMINICI, G. (2008), "Holonic production system to obtain flexibility for customer satisfaction", Journal of Service Science \& Management, Vol. I, No. 3, pp. 25I-254. 
DOMINICI, G., ARGONETO, P., RENNA, P., CUCCIA, L. (20IO), "The holonic production system: a multi agent simulation approach", iBusiness, Vol. 2, No. 3, pp. $20 \mathrm{I}-209$.

DUONG, H.-T., PACHÉ, G. (2015), “Théorie des ressources appliquée à la logistique: une identification de cinq dimensions clés", Logistique \& Management, Vol. 23, No. 2, pp. 55-72.

ELLRAM, L., TATE, W., CARTER, C. (2006), "Product-process-supply chain: an integrative approach to three-dimensional concurrent engineering", International Journal of Physical Distribution \& Logistics Management, Vol. 37, No. 4, pp. 305-330.

ENGELSETH, P. (2009), "Food product traceability and supply network integration", Journal of Business \& Industrial Marketing, Vol. 24, No. 5-6, pp. 42I-430.

ESTAMPE, D. (20I4), Supply chain performance and evaluation models, ISTE/John Wiley Er Sons, London.

FARES, M. (2009), "Brokers as experts in the French wine industry", Journal of Wine Economics, Vol. 4, No. 2, pp. 152-165.

FERRARY, M. (20I0), “Dynamique des réseaux sociaux et stratégies d'encastrement social", Revue d'économie industrielle, No. I29-130, pp. I71-202.

FLINT, D., SIGNORI, P., GOLICIC, S., Eds. (20I6), Contemporary wine marketing and supply chain management, Palgrave Macmillan, New York (NY).

FLYNN, B., HUO, B., ZHAO, X. (2010), "The impact of supply chain integration on performance: a contingency and configuration approach", Journal of Operations Management, Vol. 28, No. I, pp. 58-7I.

FOLINAS, D., MANIKAS, I., MANOS, B. (2006), “Traceability data management for food chains", British Food Journal, Vol. I08, No. 8, pp. 622-633.

FORBES, S., COHEN, D., CLEMENTS, M. (20I0), "The dissemination of information amongst supply chain partners: a New Zealand wine industry perspective", Supply Chain Forum: An International Journal, Vol. II, No. I, pp. 56-63.

FRANKEN, J. (2014), "Coordination of the California winegrape supply chain", Journal of Wine Economics, Vol. 9, No. 2, pp. I83-20I.

FRAZELLE, E. (2015), Supply chain strategy, McGraw-Hill, New York (NY), and ed.

GALASKIEWICZ, J. (20II), "Studying supply chains from a social network perspective", Journal of Supply Chain Management, Vol. 47, No. I, pp. 4-8.

GARCIA, F. (2009), Modelado y medición de performance logística en la industria del vino, Unpublished Master Thesis, Universidad National de Cyuo Mendoza.

GARCIA, F., MARCHETTA, M., FORRADELlAS, R. (20I4), "Modelling and measuring logistics performance in the wine supply chain: a research example", in BRUN, D., GUÉRIN, F. (Eds.), La logistique: ses métiers, ses enjeux, son avenir, Éditions Management ET Société, Caen, pp. 29I-3I4.

GARCIA, F., MARCHETTA, M., CAMARGO, M., MOREL, L., FORRADELlAS, R. (20I2), "A framework for measuring logistics performance in the wine industry", International Journal of Production Economics, Vol. I35, No. I, pp. 284-298.

GLIGOR, D., ESMARK, C., HOLCOMB, M. (2015), "Performance outcomes of supply chain agility: when should you be agile?", Journal of Operations Management, Vol. 33-34, pp. 7I-82.

GOODHUE, R., HEIEN, D., LEE, H., SUMNER, D. (2003), "Contracts and quality in the California wine grape industry", Review of Industrial Organization, Vol. 23, No. 3-4, pp. 267-282. 
GRANOVETTER, M. (1985), "Economic action and social structure: the problem of embeddedness", American Journal of Sociology, Vol. 9I, No. 3, pp. 48I-5IO.

GSI (2005, 2008), Wine supply chain traceability. GS1 application guideline, Brussels, available at: http://www.GSi.org (accessed March II, 2016).

GSI (20I4), Performance measurement. Business message standard, Brussels, available at: http:// www.GSi.org (accessed March II, 20I6).

GUNASEKARAN, A., PATEL, C., MCGAUGHEY, R. (2004), "A framework for supply chain performance measurement", International Journal of Production Economics, Vol. 87, No. 3, pp. 333-347.

HANDFIELD, R., NICHOLS, E. (1999), Introduction to supply chain management, Prentice Hall, Upper Saddle River (NJ).

HEANEY, B. (2013), Supply chain visibility. A critical strategy to optimize cost and service, Aberdeen Group, Boston (MA).

ISLAM, N., QUADDUS, M. (2005), "An appraisal of uncertainties in the Western Australian wine industry supply chain", Proceedings of the 49th Annual Conference of the Australian Agricultural \& Resource Economics Society, Coffs Harbour, pp. I-I5 (CD-rom).

ITÇAINA, X., ROGER, A., SMITH, A. (20I6), Varietals of capitalism: a political economy of the changing wine industry, Cornell University Press, Ithaca (NY).

KAJÜTER, P., KULMALA, H. (2005), Open-book accounting in networks: potential achievements and reasons for failures, Management Accounting Research, Vol. I6, No. 2, pp. 179-204.

KIM, Y., CHOI, T., YAN, T., DOOLEY, K. (2OII), "Structural investigation of supply networks: a social network analysis approach", Journal of Operations Management, Vol. 29, No. 3, pp. I94-2II.

KNOKE, D., YANG, S. (2008), Social network analysis, Sage, Thousand Oaks (CA).

LAM, H.-Y., CHOY, K.-L., HO, G.-T., KWONG, C.-K., LEE, C.-K. (2013), "A real-time risk control and monitoring system for incident handling in wine storage", Expert Systems with Applications, Vol. 40, No. 9, pp. 3665-3678.

LAMBERT, D., BURDUROGLU, R. (2000), "Measuring and selling the value of logistics", International Journal of Logistics Management, Vol. II, No. I, pp. I-I8.

LAMBERT, D., COOPER, M., PAGH, J. (I998), “Supply chain management: implementation issues and research opportunities", International Journal of Logistics Management, Vol. 9, No. 2, pp. I-2O.

LAZZARINI, S., CHADDAD, F., COOK, M. (200I), "Integrating supply chain and network analyses: the study of netchains", Journal on Chain \& Network Science, Vol. I, No. I, pp. 7-22.

LEE, P. (2005), "Measuring supply chain integration: a social network approach", Supply Chain Forum: An International Journal, Vol. 6, No. 2, pp. 58-67.

LIU, L. (20II), "Research on the management system of enterprises using modern logistics supply chain theory", Procedia Engineering, Vol. 24, pp. 72I-725.

MAC CAWLEY, A. (2014), The international wine supply chain: challenges from bottling to the glass, Unpublished Doctoral Dissertation, Georgia Institute of Technology, August, available at: http://hd1.handle.net/1853/52213 (accessed November I2, 2015).

MACKELPRANG, A., ROBINSON, J., BERNARDES, E., WEBB, G. (20I4), “The relationship between strategic supply chain integration and performance: a meta-analytic 
evaluation and implications for supply chain management research", Journal of Business Logistics, Vol. 35, No. I, pp. 71-96.

MIN, H., ZHOU, G. (2002), "Supply chain modeling: past, present and future", Computers \& Industrial Engineering, Vol. 43, No. I, pp. 231-249.

MITCHELL, R., SCHREIBER, C. (2007), "Wine tourism networks and clusters: operation and barriers in New Zealand", in Edwin, M. (Ed.), Micro-clusters and networks: the growth of tourism, Elsevier, Oxford, pp. 79-I05.

MUCHIRI, P., PINTELON, L., MARTIN, H., DE MEYER, A. (20IO), “Empirical analysis of maintenance performance measurement in Belgian industries", International Journal of Production Research, Vol. 48, No. 20, pp. 5905-5924.

MUELLER, R., BUERGELT, D., SEIDEL-LASS, L. (2007), "Supply chains and social network analysis", Proceedings of the First International European Forum on Innovation \& System Dynamics in Food Networks, Innsbruck-Igls, pp. I-I2 (CD-rom).

PHILIPPART, M., VIEIRA, D. (2OI4), "Measuring and managing projects in extended enterprise: a value creation focus based on intangible assets", Journal of Modern Project Management, Vol. I, No. 3, pp. 2I-29.

POMARICI, E., BOCCIA, F., CATAPANO, D. (2012), "The wine distribution systems over the world: an explorative survey", New Medit, Vol. II, No. 4, pp. 23-32.

PRETORIUS, I., HØJ, P. (2005), "Grape and wine biotechnology: challenges, opportunities and potential benefits", Australian Journal of Grape \& Wine Research, Vol. II, No. 2, pp. 83-108.

SAGLiETto, L., FUlCONIS, F., BÉDÉ, D., DE ALMEIDA GOES, J., FORRADELlaS, R. (2016), "Wine industry supply chain: international comparative study using social network analysis", Supply Chain Forum: An International Journal, Vol. I7, No. 2, pp. 55-67.

SEAL, W., CULLEN, J., DUNLOP, A., BERRY, T., AHMED, M. (1999), “Enacting a European supply chain: a case study on the role of management accounting", Management Accounting Research, Vol. Iо, No. 3, pp. 303-322.

SIDLOVITS, D., KATOR, Z. (2007), "Characteristics of vertical coordination in the Hungarian wine sector", Proceedings of the 104th EAAE Seminar on Agricultural Economics \& Transition, Budapest, pp. I-28 (CD-rom).

SOMOGYI, S., GYAU, A., LI, E., BRUWER, J. (20I0), “Enhancing long-term grape grower/ winery relationships in the Australian wine industry", International Journal of Wine Business Research, Vol. 22, No. I, pp. 27-4I.

SONG, H., YU, K., GANGULY, A., TURSON, R. (20I6), "Supply chain network, information sharing and SME credit quality", Industrial Management \& Data Systems, Vol. II6, No. 4, pp. $740-758$.

STANK, T., GOLDSBY, T., VICKERY, S., SAVITSKIE, K. (2003), “Logistics service performance: estimating its influence on market share", Journal of Business Logistics, Vol. 24, No. I, pp. 27-55.

STEINER, B. (2012), "Contracting in the wine supply chain with bilateral moral hazard, residual claimancy and multi-tasking", European Review of Agricultural Economics, Vol. 39, No. 3, pp. 369-395.

STEVENSON, W. (20I4), Operations management, McGraw-Hill, New York (NY), $12^{\text {th }}$ ed.

STEWART, G. (1995), "Supply chain performance benchmarking study reveals keys to supply chain excellence", Logistics Information Management, Vol. 8, No. 2, pp. 38-44. 
TAN, K., KANNAN, V., HANDFIELD, R., GHOSH, S. (I999), “Supply chain management: an empirical study of its impact on performance", International Journal of Operations \& Production Management, Vol. I9, No. I0, pp. I034-I052.

THAKUR, M., HURBURGH, C. (2009), “Framework for implementing traceability system in the bulk grain supply chain", Journal of Food Engineering, Vol. 95, No. 4, pp. 617-626.

UNIDO (20II), Industrial value chain diagnostics: an integrated tool, United Nations Industrial Development Organization, Vienna, available at: https://www.unido.org/fileadmin/user_media/MDGs/IVC_Diagnostic_Tool.pdf (accessed May 3I, 20I5).

VALENZUELA, L., MATURANA, S. (2016), "Designing a three-dimensional performance measurement system (SMD3D) for the wine industry: a Chilean example", Agricultural Systems, Vol. I42, pp. II2-I2I.

VUKATANA, K., SEVRANI, K., HOXHA, E. (20I6), “Wine traceability: a data model and prototype in Albanian context", Foods, Vol. 5, No. I, pp. I-II.

WANG, B., CHILDERHOUSE, P., KANG, Y., HUO, B., MATHRANI, S. (20I6), “Enablers of supply chain integration: interpersonal and interorganizational relationship perspectives", Industrial Management \& Data Systems, Vol. ir6, No. 4, pp. 838-855.

WASSERMAN, S. (1994), Social network analysis: methods and applications, Cambridge University Press, Cambridge.

WOODS, T., SCHIEFFER, J., SAGHAIAN, S. (20II), "Winery integration strategies in the mid-South and mid-Atlantic states", Journal of Agribusiness, Vol. 29, No. I, pp. 83-95.

WU, L., CHUANG, C., HSU, C. (20I4), "Information sharing and collaborative behaviors in enabling supply chain performance: a social exchange perspective", International Journal of Production Economics, Vol. I48, pp. I22-I32. 


\section{APPENDIX 1}

\section{Examples of WSC}

I) Mendoza Argentina network of WSC

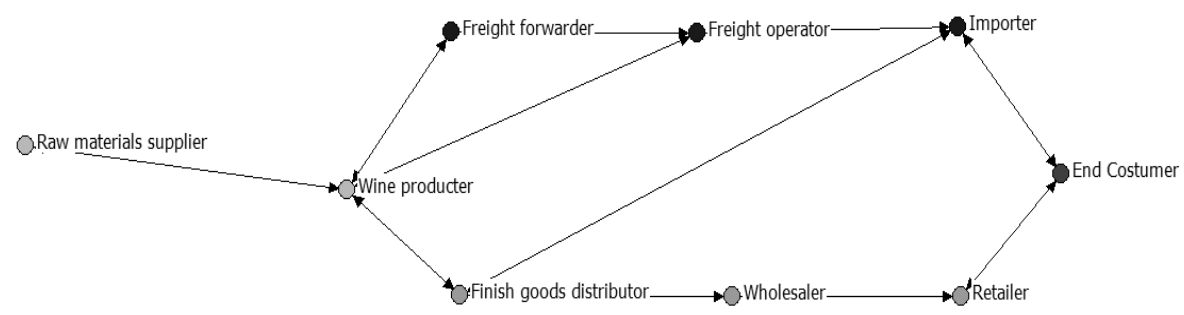

2) South East of France network of WSC

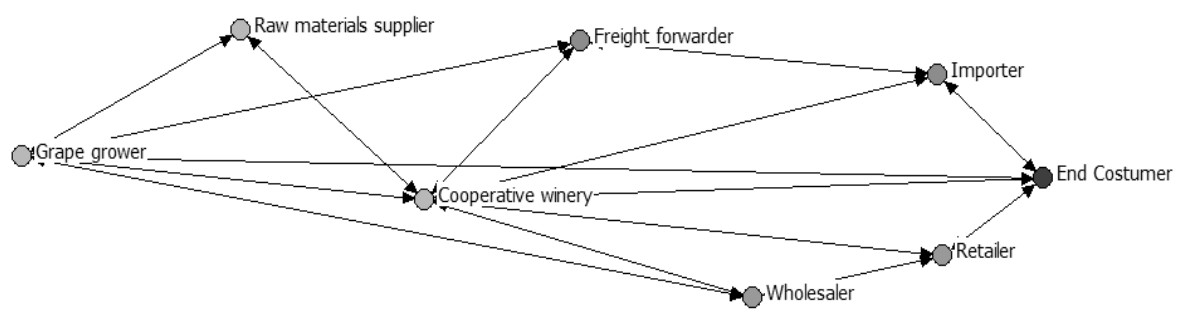

\section{APPENDIX 2}

\section{Proposed performance indicators}

\section{Relationship between raw material suppliers and grape growers}

Contractual relationship: Order delivery.

Agreement relationship to the GS1 standard: For each delivery, the raw material supplier provides the grape grower the identification of the dry goods in contact with the wine (bottles, corks, capsules, barrels, kegs, labels, etc.). The grape grower connects the characteristics of the raw materials with the quality of the material and the wine production. 
Joint effort relationship: The grape grower returns information to the raw material supplier.

Performance indicators in terms of monitoring of different flows:

- quality of raw materials,

- efficiency of raw materials,

- possible improvement to make,

- nature of the defective products.

Performance indicators in terms of relationship monitoring:

- order purchasing profile (communication means, information systems),

- contract negotiation/renegotiation,

- quality of exchanges regarding refusals and disputes on a real-time basis.

\section{Relationship between raw material suppliers and wine producers}

Contractual relationship: Order delivery.

Agreement relationship to the GS1 standard: For each delivery, the raw material supplier provides the wine producer the identification of the dry goods in contact with the wine (bottles, corks, capsules, barrels, kegs, labels, etc.). The wine producer connects the characteristics of the raw materials with the quality of the material and the wine production.

Joint effort relationship: The wine producer returns information to the raw material supplier.

Performance indicators in terms of monitoring of different flows:

- quality of raw materials,

- efficiency of raw materials,

- possible improvement to make,

- nature of the defective products. 
Performance indicators in terms of relationship monitoring:

- order purchasing profile (communication means, information systems),

- contract negotiation/renegotiation,

- quality of exchanges regarding refusals and disputes on a real-time basis.

\section{Relationship between raw material suppliers and fillers/packers}

Contractual relationship: Order delivery.

Agreement relationship to the GS1 standard: For each delivery, the raw material supplier provides the filler/packer the identification of the dry goods in contact with the wine (bottles, corks, capsules, barrels, kegs, labels, etc.). The filler/packer connects the characteristics of the raw materials with the quality of the material, the batch of filled bottles and marketed boxes.

Joint effort relationship: The filler/packer returns information to the raw material supplier.

Performance indicators in terms of monitoring of different flows:

- quality of raw materials,

- efficiency of raw materials,

- possible improvement to make,

- nature of the defective products.

Performance indicators in terms of relationship monitoring:

- order purchasing profile (communication means, information systems),

- contract negotiation/renegotiation,

- quality of exchanges regarding refusals and disputes on a real-time basis. 


\section{Relationship between grape growers and wine producers}

Contractual relationship: Order delivery.

Agreement relationship to the GS1 standard: For each delivery, the grape grower provides the producer the GLN of the parcel or field from which the grapes originate, the grape variety and the date of harvest. The reception date must also be recorded. The producer connects the relevant details to the various wine treatments.

Joint effort relationship: The producer returns information to the grape grower.

Performance indicators in terms of monitoring of different flows:

- type of storage as from the delivery of grapes (collecting and winemaking vats),

- production and/or wine-blending techniques (destemmer, grape grinder, wort cooler, press),

- precise description of the procedures used for the production of each wine,

- monitoring of the final product delivered to bottlers and/or cellars and/or bulk wine distributors.

Performance indicators in terms of relationship monitoring:

- report on the period covered by the contract,

- quality assurance of the production and/or wine-blending of the wines,

- biochemical analysis and tasting of each type of wine,

- quality of exchanges regarding refusals and disputes.

\section{Relationship between grape growers and fillers/ packers}

Contractual relationship: Order delivery. 
Agreement relationship to the GS1 standard: For each delivery, the grape grower provides the filler/packer the GLN of the parcel or field from which the grapes originate, the grape variety and the date of harvest; the reception date must also be recorded. The filler/packer connects the relevant characteristics to the batch of filled bottles and boxes to ship.

Joint effort relationship: The filler/packer returns information to the grape grower.

Performance indicators in terms of monitoring of different flows:

- identification of the dry goods in contact with the wine (bottles, corks, capsules, barrels, kegs, labels, etc.),

- quality of the water used to clean the filling equipment, chemicals used to clean, etc.,

- sales level of batch of bottles, boxes and pallets,

- dispatching of the packaged goods in the correct quantity and per recipient.

Performance indicators in terms of relationship monitoring:

- quality assurance of filling and separation techniques,

- quality of exchanges regarding refusals and disputes on a real-time basis,

- contract negotiation/renegotiation.

\section{Relationship between grape growers and cellar door sales}

Contractual relationship: Order delivery.

Agreement relationship to the GS1 standard: For each delivery, the grape grower provides the cellar door sales the GLN of the parcel or field from which the grapes originate and the date of harvest. The cellar door sales connect the relevant characteristics to the wine produced from these grapes.

Joint effort relationship: The cellar door sales return information to the grape grower. 
Performance indicators in terms of monitoring of different flows:

- analyses results of sample tasting,

- analyses results of the wine received depending on the place of the delivery (destemmer, grape grinder, wort cooler, press, collecting and wine-making vats),

- dispatching of products sold according to type, quantity and recipient.

Performance indicators in terms of relationship monitoring:

- order purchasing profile (communication means, information systems),

- quality of exchanges regarding refusals and disputes,

- contract negotiation/renegotiation.

\section{Relationship between wine producers and bulk wine distributors}

Contractual relationship: Order delivery.

Agreement relationship to the GS1 standard: For each delivery, the wine producer provides the bulk wine distributor the GTIN and the batch number. The identification of bulk wine containers is recorded upon arrival. The bulk wine distributor connects the relevant characteristics to the wine to market.

Joint effort relationship: The bulk wine distributor returns information to the wine producer.

Performance indicators in terms of monitoring of different flows:

- sample tasting analyses results depending on the type of product in the container (mixed products, unique product),

- quality and quantity of the shipping container,

- type of preservation and storage,

- dispatching of products sold according to type, quantity and recipient. 
Performance indicators in terms of relationship monitoring:

- approval or refusal of the wine (in case of refusal, the wine returns to the designated source),

- quality of exchanges regarding refusals and disputes on a real-time basis,

- order purchasing profile (communication means, information systems).

\section{Relationship between wine producers and fillers/ packers}

Contractual relationship: Order delivery.

Agreement relationship to the GS1 standard: For each delivery, the wine producer provides the filler/packer the GTIN and the batch number. The information received and recorded also includes the quantity of wine delivered. The filler/packer connects the relevant characteristics of the wine delivered to the batch of filled bottles and boxes to ship.

Joint effort relationship: The filler/packer returns information to the producer.

Performance indicators in terms of monitoring of different flows:

- identification of the dry goods in contact with the wine (bottles, corks, capsules, barrels, kegs, labels, etc.),

- quality of the water used to clean the filling equipment, chemicals used to clean, etc.,

- sales level of batch of bottles, boxes and pallets,

- dispatching of the packaged goods in the correct quantity and per recipient.

Performance indicators in terms of relationship monitoring:

- quality assurance of filling and separation techniques,

- quality of exchanges regarding refusals and disputes,

- contract negotiation/renegotiation. 


\section{Relationship between wine producers and freight forwarders}

Contractual relationship: Order delivery.

Agreement relationship to the GS1 standard: For each delivery, the wine producer provides the freight forwarder the GTIN and the batch number. The information received and recorded also includes the quantity of wine delivered. The freight forwarder connects the relevant characteristics of the batch of bottles filled to the successive freight operators.

Joint effort relationship: The freight forwarder returns information to the producer.

Performance indicators in terms of monitoring of different flows:

- freight operators' profiles and means of transportation,

- real-time monitoring of the waybill,

- periodical report on related administrative operations (customs, insurances, formalities).

Performance indicators in terms of relationship monitoring:

- order purchasing profile (communication means, information systems),

- quality assurance of contract fulfilment,

- contract negotiation/renegotiation.

\section{Relationship between freight forwarders-freight operators}

Contractual relationship: Order delivery.

Agreement relationship to the GS1 standard: For each delivery, the freight forwarder provides the freight operator the GTIN and the batch number. The information received and recorded also includes the quantity of wine delivered. The freight operator connects the relevant characteristics to the products shipped. 
Joint effort relationship: The freight operator returns information to the freight forwarder.

Performance indicators in terms of monitoring of different flows:

- profiles of distribution channels, clients and markets,

- real-time monitoring of the waybill,

- periodical report on related administrative operations (customs, insurances, formalities).

Performance indicators in terms of relationship monitoring:

- order purchasing profile (communication means, information systems),

- quality assurance of contract fulfilment,

- contract negotiation/renegotiation.

\section{Relationship between freight operators and importers}

Contractual relationship: Order delivery.

Agreement relationship to the GS1 standard: For each delivery, the freight operator provides the importer the GTIN and the batch number. The information received and recorded also includes the quantity of wine delivered. The importer connects the relevant characteristics to consumption units (bottles, boxes) to market abroad.

Joint effort relationship: The importer returns information to the freight operator.

Performance indicators in terms of monitoring of different flows:

- profiles of distribution channels,

- real-time monitoring of the waybill,

- shipment dispatching (clients, target country, products),

- periodical report on related administrative operations (customs, insurances, formalities), 
- monitoring of export documents.

Performance indicators in terms of relationship monitoring:

- order purchasing profile (communication means, information systems),

- quality assurance of contract fulfilment,

- contract negotiation/renegotiation.

\section{Relationship between bulk wine distributors and transit cellars}

Contractual relationship: Order delivery.

Agreement relationship to the GS1 standard: For each delivery, the bulk wine distributor provides the transit cellar the identification of the bulk wine container that is recorded upon delivery. The transit cellar connects the relevant characteristics to the making, sampling, analysis and shipment.

Joint effort relationship: The transit cellar returns information to the bulk wine distributor.

Performance indicators in terms of monitoring of different flows:

- sample tasting analyses results,

- quality and quantity of the shipping container,

- results of the wine-making,

- quantity of wine shipped (in litres) and number of batches of wine in bulk.

Performance indicators in terms of relationship monitoring:

- approval or refusal of the wine (in case of refusal, the wine returns to the designated source),

- order purchasing profile (communication means, information systems),

- quality assurance of contract fulfilment. 


\section{Relationship between transit cellars and fillers/packers}

Contractual relationship: Order delivery.

Agreement relationship to the GS1 standard: For each delivery, the transit cellar provides the filler/packer the identification of the bulk wine container that is recorded upon arrival. The filler/packer connects the relevant characteristics to the batch of bottles to fill and the boxes to ship.

Joint effort relationship: The filler/packer returns information to the transit cellar.

Performance indicators in terms of monitoring of different flows:

- identification of the dry goods in contact with the wine (bottles, corks, capsules, barrels, kegs, labels, etc.),

- quality of the water used to clean the filling equipment, chemicals used to clean, etc.,

- sales level of batches of bottles,

- dispatching of products sold according to type, quantity and recipient.

Performance indicators in terms of relationship monitoring:

- order purchasing profile (communication means, information systems),

- quality assurance of contract fulfilment.

\section{Relationship between fillers/packers and finished good distributors}

Contractual relationship: Order delivery.

Agreement relationship to the GS1 standard: For each delivery, the filler/packer provides the finished good distributor the identification of the pallets and boxes that are recorded upon delivery. The finished good distributor 
connects the relevant characteristics to the storage, repackaging (new packaging and label) and distribution of finished goods.

Joint effort relationship: The finished good distributor returns information to the filler/packer.

Performance indicators in terms of monitoring of different flows:

- storage profile,

- monitoring of incoming and outgoing pallets (non modified, newly created),

- dispatching of products sold according to type, quantity and recipient,

- market profiles (local, national, international).

- real-time monitoring of the waybill,

- periodical report on related administrative operations (customs, insurances, formalities).

Performance indicators in terms of relationship monitoring:

- order purchasing profile (communication means, information systems),

- quality assurance of contract fulfilment,

- quality of exchanges regarding refusals and disputes.

\section{Relationship between fillers/packers and freight operators}

Contractual relationship: Order delivery.

Agreement relationship to the GS1 standard: For each delivery, the filler/packer provides the freight operator the identification of the pallets and boxes that are recorded upon delivery. The freight operator connects the relevant characteristics of the wine to the products shipped.

Joint effort relationship: The freight operator returns information to the filler/packer. 
Performance indicators in terms of monitoring of different flows:

- profiles of distribution channels, clients and markets,

- real-time monitoring of the waybill,

- periodical report on related administrative operations (customs, insurances, formalities).

Performance indicators in terms of relationship monitoring:

- order purchasing profile (communication means, information systems),

- quality assurance of contract fulfilment,

- contract negotiation/renegotiation.

\section{Relationship between finished good distributors and wholesalers}

Contractual relationship: Order delivery.

Agreement relationship to the GS1 standard: For each delivery, the finished good distributor provides each wholesaler the identification of the pallets and boxes that are recorded upon delivery. The wholesaler connects the relevant characteristics of the wine to the repackaging and relabeling of the products.

Joint effort relationship: The wholesaler returns information to the distributor.

Performance indicators in terms of monitoring of different flows:

- qualitative monitoring of the pallets and boxes received,

- monitoring of changes made on the pallets,

- shipment dispatching to various retailers.

Performance indicators in terms of relationship monitoring:

- order purchasing profile (communication means, information systems),

- quality assurance of contract fulfilment. 


\section{Relationship between finished good distributors and retailers}

Contractual relationship: Order delivery.

Agreement relationship to the GS1 standard: For each delivery, the finished good distributor provides each retailer the identification of the pallets and boxes that are recorded upon delivery. The retailer connects the relevant characteristics to the consumption units (bottles, boxes) sold to the stores.

Joint effort relationship: The retailer returns information to the wholesaler.

Performance indicators in terms of monitoring of different flows:

- profile of the end customer (hypermarket, restaurant, etc.),

- shipment dispatching,

- monitoring of pallets (quantity, content, date of packaging),

- profile of returned defective products.

Performance indicators in terms of relationship monitoring:

- order purchasing profile (communication means, information systems),

- quality assurance of contract fulfilment.

\section{Relationship between finished good distributors and importers}

Contractual relationship: Order delivery.

Agreement relationship to the GS1 standard: For each delivery, the finished good distributor provides each importer the identification of the pallets and boxes that are recorded upon delivery. The importer connects the relevant characteristics to the consumption units (bottles, boxes) to sell abroad.

Joint effort relationship: The importer returns information to the finished good distributor. 
Performance indicators in terms of monitoring of different flows:

- profile of the foreign end customer,

- shipment dispatching,

- profile of distribution channels,

- profile of country of destination.

Performance indicators in terms of relationship monitoring:

- order purchasing profile (communication means, information systems),

- quality assurance of contract fulfilment,

- contract negotiation/renegotiation.

\section{Relationship between finished good distributors and end customers}

Contractual relationship: Order delivery.

Agreement relationship to the GS1 standard: For each delivery, the finished good distributor provides the end customer the identification of the wine's origin.

Joint effort relationship: The end customer returns information to the finished good distributor.

Performance indicators in terms of monitoring of different flows:

- statistics concerning the wine bought,

- profile of end customers.

Performance indicators in terms of relationship monitoring:

- approval or refusal of wine in terms of purchase.

\section{Relationship between retailers and end customers}

Contractual relationship: Order delivery. 
Agreement relationship to the GS1 standard: For each delivery, the retailer provides the end customer the wine's origin.

Joint effort relationship: The end customer returns information to the retailer.

Performance indicators in terms of monitoring of different flows:

- statistics concerning the wine bought,

- profile of end customers.

Performance indicators in terms of relationship monitoring:

- approval or refusal of wine in terms of purchase.

\section{Relationship between importers and end customers}

Contractual relationship: Order delivery.

Agreement relationship to the GS1 standard: For each delivery, the importer provides the end customer the wine's origin.

Joint effort relationship: The end customer returns information to the importer.

Performance indicators in terms of monitoring of different flows:

- statistics concerning the wine bought,

- profile of end customers.

Performance indicators in terms of relationship monitoring:

- approval or refusal of wine in terms of purchase. 